XАPIH

Сергій Анатолійович

kharin_sa@kneu.dp.ua

д.т.н., професор, Криворізький економічний інститут ДВНЗ

"Київський національний економічний університет імені Вадима Гетьмана"
УДК 338.26:621

ІННОВАЦІЙНИЙ МЕНЕДЖМЕНТ ПРОЕКТІВ РОЗВИТКУ

ЕЛЕКТРОМОБІЛЬНОСТІ: ЗАРУБІЖНИЙ ДОСВІД I УКРАЇ̈А

\section{INNOVATIVE MANAGEMENT OF PROJECTS FOR ELECTRIC MOBILITY DEVELOPMENT: FOREIGN EXPERIENCE AND UKRAINE}

ПУРІЙ

Ганна Володимирівна puriy_av@kneu.dp.ua

DOI: https://doi.org/10.37634/efp.2020.5.4

KHARIN Serhii Anatoliiovych - Doctor of Engineering, Professor, Kryvyi Rih Economics Institute of Kyiv National Economic University after Vadym Hetman

PURII Hanna Volodymyrivna - PhD in Economics, Associate Professor, Kryvyi Rih Economics Institute of Kyiv National Economic University after Vadym Hetman

У статті розглянуто різні аспекти розвитку виробництва електромобілів в ряді провідних зарубіжних краӥн. Досліджується динаміка зростання питомої ваги електромобілів у загальному обсязі транспорту і його прогнозні показники з урахуванням країн, які планують повний перехід на електромобільність. Відзначено, щьо у багатьох зарубіжних краӥнах дотації і податкові знижки для власників електромобілів виступають в якості важливого інструменту державного стимулювання. Аналізується можливість випуску українських електромобілів. Підкреслюється, що виробництво електромобілів дозволяє об'єднувати два виграшних економічних фактора - інноваційність продукиії і масове ї̈ виробництво.

$* * *$

В статье рассмотрены различные аспекты развития производства электромобилей в ряде ведущих зарубежных стран. Исследуется динамика роста удельного веса электромобилей в общем объеме транспорта и его прогнозные показатели с учетом стран, планирующих полный переход на электромобильность. Отмечено, что во многих зарубежных странах дотачии и налоговые скидки для собственников электромобилей выступают в качестве важного инструмента государственного стимулирования. Анализируется возможность выпуска украинских электромобилей. Подчеркивается, что производство электромобилей позволяет объединять два выцгрышных экономических фактора - инновачионность продукиии и массовое ее производство.

$$
* * *
$$

The research considers various aspects of electric vehicle production in some leading foreign countries. Dynamics of specific weight of electric vehicles in total transport and its forecast indices are under analysis considering those of the countries planning complete transition to electric mobility. Urgency of building an expanded network of charging stations of various capacity is pointed out. It is revealed that Volkswagen, the world largest automobile concern, is going to introduce much more new designs of electric vehicles than it considered before - 70 instead of 50 by 2028. It is planned to produce more electric vehicles - from 15 to $22 \mathrm{mln}$ in the decade to follow. Besides, the share of electric vehicles in the concern's total production is to exceed $40 \%$ by 2030. It is indicated that 44bln euros will be invested into designing new VW automobiles in the nearest 5 years. It is significant that in many foreign countries there are subsidies and tax reduction for electric vehicle owners which are used as an important tool of the state incentives. Besides, special attention is paid to improvement and development of production of batteries for electric cars, especially in the EU countries. The authors suggest schemes of elaborating electric mobile innovations and power supply for electric mobility providing green and economic solutions for generating power for electric cars by wind generators. Potential production of Ukrainian electric cars is under analysis. It is highlighted that electric vehicle production allows combining two economically beneficial factors - innovative character of a product and its large-scale production. In this case, there will be a novelty effect and huge unsatisfied demand as well as scale saving.

Ключові слова: інновачії, менеджмент, електромобілі, концерн, розвиток, випуск, економічні фактори, інструмент стимулювання, масове виробництво, зарубіжні країни, прогнозні показники, продукція, енергія, інвестиції

Ключевые слова: инновачии, менеджмент, электромобили, кониерн, развитие, выпуск, экономические факторы, инструмент стимулирования, массовое производство, зарубежные страны, прогнозные показатели, продукция, энергия, инвестиичи

Keywords: innovation, management, electric cars, concern, development, production, economic factors, incentive instrument, mass production, foreign countries, forecast indicators, products, energy, investments

\section{ВСТУП}

Дуже перспективним в даний час інноваційним напрямком у світовій економіці є розробка і виробництво електромобілів. Електромобілі мають низку унікальних властивостей, що роблять їх використання в великих містах особливо доречним: можливість експлуатації у міських тунелях, що важко за умовами вентиляції для традиційних машин. Нарешті, відсутні додаткові витрати енергії у міських «пробках», тоді як автомобілі 3 двигунами внутрішнього згоряння 
витрачають в них палива значно більше, ніж зазвичай. Екологічні ж переваги електромобілів очевидні. Слід вказати і значно менші витрати електромобілів на енергію, ніж звичайних автомобілів на традиційне паливо.

Незважаючи на динамічний розвиток електромобільності у світі теоретична проробка даної проблеми і комплексне вивчення практичного досвіду управління такими складними інноваційними процесами виконані ще далеко не повно і $є$ актуальними.

META роботи - дослідити у комплексному вигляді питання інноваційного менеджменту створення і виробництва електромобілів у провідних зарубіжних країнах та виконати аналіз різних факторів, що пов'язані $з$ можливостю виробництва українських електромобілів.

\section{МЕТОДИ ДОСЛІДЖЕННЯ}

У процесі дослідження використано методи аналізу і синтезу. Дослідження базується на офіційних даних автомобільних концернів, світової економічної статистики та Інтернет-ресурсах.

\section{РЕЗУЛЬТАТИ}

Електромобілі склали 31 \% всіх нових машин, проданих у Норвегії в 2018 р., що є найвищим (у відносному розумінні) показником в світі. Відомо також, що країна планує до 2025 р. повністю відмовитися від бензинових двигунів. Норвегія $є$ найбільшим ринком збуту Tesla в Європі. За минулий рік американський виробник поставив туди більше 8600 автомобілів. Очікується, що в 2019 р. число проданих машин різко зросте, коли на норвезькому ринку з'явиться нова Tesla Model 3. Вказується також, що продажі екологічних автомобілів виросли на 40 \% порівняо з 2017 р. Таким чином, 3 двох мільйонів машин на дорогах Норвегії 10 \% складають екологічні автомобілі [1].

Інша Скандинавська країна, Швеція, заборонить двигуни внутрішнього згоряння в 2030 р. Вона виявиться в одній групі 3 такими державами, як Данія, Ізраїль, Ірландія, Ісландія, Нідерланди (а також 3 французькою столицею Парижем). Всі вони теж оголосили про намір через десять років припинити реєстрацію автомобілів 3 двигунами внутрішнього згоряння.

Найбільший у світі німецький концерн Volkswagen планує вивести на ринок значно більше моделей електромобілів, ніж планувалося раніше. До 2028 р. у продажу з'явиться майже 70 нових моделей машин 3 електроприводом. Раніше концерн заявляв про плани зі створення 50 моделей електрокарів. У найближчі десять років 3 конвеєрів VW повинні зійти 22 млн. електромобілів замість запланованих раніше 15 млн. Частка електрокарів в загальному обсязі вироблених концерном автомобілів до 2030 р. повинна скласти не менше $40 \%$ (близько 4 млн. машин на рік, якщо брати до уваги нинішній рівень виробництва), говориться в опублікованій на сайті концерну заяві. Далі вказується, що в розробку нової техніки, зокрема електродвигунів, технологій автономного водіння і цифровізації різних систем, концерн в найближчі 5 років інвестує 44 млрд. євро, повідомив глава VW Херберт Дис [2].

Дотації і податкові знижки для власників електромашин в ФРН виступають як важливий інструмент державного впливу на розвиток цього прогресивного виду транспорту. За даними [3], щоб полегшити німецьким автомобілістам перехід на електромобілі, держава буде доплачувати їм в 2021-22 pр. 4000 євро за придбання машини вартістю в межах 40000 євро, а після 2022 р. - 3000 євро.

Деякий час назад японська корпорація Sony несподівано для всіх представила прототип електромобіля Vision-S на виставці високих технологій в Лас-Вегасі. У створенні машини широко задіяні міжнародні зв'язки. В якості своїх німецьких партнерів Sony називає компанії Bosch, ZF, Continental i Here. Vision-S використовує також технології від Magna Steyr, Benteler, Nvidia, Blackberry i Qualcomm, що значно прискорює розвиток електромобілів [4].

У листопаді 2019 р. Volkswagen дав старт серійного виробництва електромобіля ID.3. Він буде сходити з конвеєра в Цвіккау - місті в федеральній землі Саксонія. Це буде перший в Німеччині завод з випуску тільки електричних автомобілів. Volkswagen також вирішив, що другим його підприємством, яке повністю сконцентрується на виробництві електромобілів, стане до 2022 р. завод в Емдені, де поки випускають VW Passat. Активно поширюється автоматизація підприємства: у виробництві і збірці електромобілів у Цвіккау будуть брати участь 1700 промислових роботів [5].

Наприкінці 2019 р. стало відомо, що американська компанія, що спеціалізується на виробництві електромобілів і розробці нових технологій для акумулювання електроенергії, Tesla, одним із співзасновників якої $є$ Ілон Маск, інвестує в великий завод під Берліном 4 млрд. євро. На заводі в Грюнхайде Tesla планує випускати спочатку до 150 тис. електрокарів щорічно, а в перспективі й до 500 тис. Очікується, що першими 3 конвеєра зійдуть машини Model Y, пише газета Bild am Sonntag. У разі згоди з боку уряду ФРН i Євросоюзу Tesla може розраховувати на державну підтримку у розмірі близько 300 млн. євро [6].

Як відомо, свій перший завод за межами США Tesla відкрила в Шанхаї. На початку січня 2020 р. компанія почала масові поставки електромобілів Model 3, вироблених на шанхайському заводі Gigafactory 3 [7].

Європейська комісія схвалила плани Німеччини і шести інших держав Євросоюзу виділити загалом 3,2 млрд. євро на субсидії для створення європейського центру з виробництва елементів акумуляторних батарей [8].

Виробництво електромобілів дозволяє поєднувати два виграшних економічних фактора - безумовну інноваційність продукції і масове іiі виробництво: у цьому випадку буде мати місце ефект як від новизни, великого незадоволеного попиту, так і від економії на масштабі.

Україна, без сумніву, володіє певними можливостями для виробництва електромобілів: наявність великих запасів залізної руди, розвинене металургійне виробництво, наявність родовищ літію, який є сировиною для акумуляторів, забезпеченість електроенергією, часткова можливість забезпечення виробництва трудовими ресурсами.

Водночас негативними чинниками, здатними стри- 
мувати розвиток електромобільності в країні є: відсутність значущого досвіду проектування і виробництва конкурентоспроможних на світовому ринку електромобілів будь-якого класу, акумуляторів великої ємності, автомобільних електродвигунів, зарядних пристроїв, підготовлених для зазначених вище цілей інженерних та робітничих кадрів, системи їх підготовки, великий відтік потенційно придатних для таких цілей кадрів за кордон, який триває, крайня обмеженість інвестиційних ресурсів, відсутність в країні заводів, що випускають обладнання для виробництва електромобілів, їх елементів і зарядних пристроїв.

Для розвитку виробництва в нашій країні електромобілів було б доцільним створення центру інновацій, координуючого зусилля різних структур і забезпечуючих взаємодію 3 закордонними партнерами (рис. 1).

У рамках роботи центру може здійснюватися взає- модія зарубіжних партнерів в особі виробників і розробників електромобілів і окремих їх елементів, зарядних пристроїв, наукових установ, інвесторів, окремих фахівців у різних областях, а також представників вітчизняних науково-дослідних інститутів, університетів, банків, виробничих суб'єктів та інших структур, спрямоване на забезпечення сприятливих умов для розвитку електромобільності.

У нашій країні, беручи до уваги низьку ефективність і сильну зношеність обладнання теплових електростанцій, а також прогресивні світові тенденції (до 2020 р. в Данії частка вітрових станцій у виробництві електроенергії наблизилася до 50\%, а у ФРН досягла $25 \%$ було б дуже доцільно розвиток електромобільності поєднувати 3 прискореним виробництвом всередині країни і введенням в експлуатацію вітрових електроустановок (рис. 2).

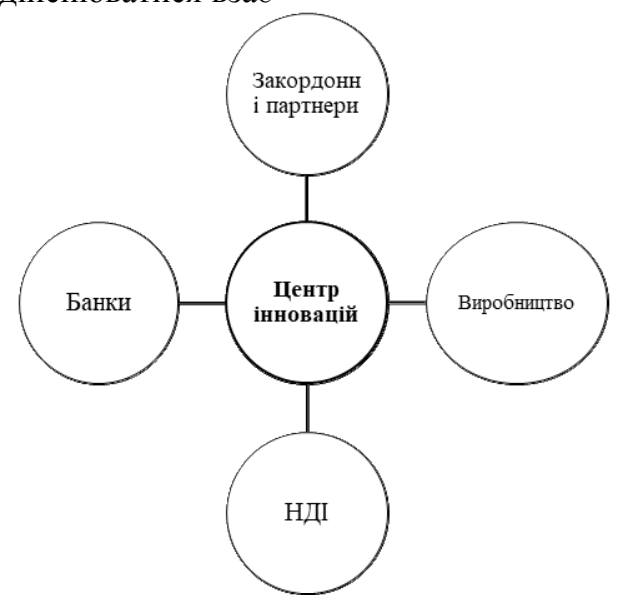

Рис. 1. Центри інновацій для електромобільності
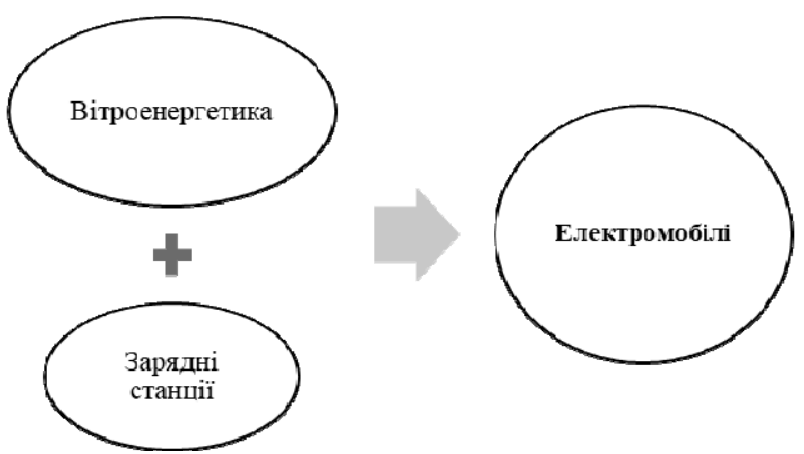

Рис. 2. Екологічна схема виробки енергї для електромобілів

Подібні заходи могли б принести особливу користь, якби здійснювалися у співпраці з провідними світовими виробниками вітрогенераторів, наприклад, Vestas Wind Systems (Данія), General Electric (США), Enercon GmbH i Nordex (ФPH), Gamesa Corporacion Tecnologica (Іспанія). Саме вітрові електростанції могли б забезпечувати виробництво первинної екологічно чистої електроенергії, яка за допомогою розвитої мережі зарядних станцій, забезпечувала б потреби великої кількості електромобілів.

\section{ВИСНОВКИ}

Таким чином, аналіз розвитку інноваційних процесів, проектування і виробництва електромобілів і пов'язаних 3 ними чинників, у т.ч. інфраструктурного характеру, дозволивши, зокрема, встановити наступне. Увага до електромобільності у багатьох, особливо в економічно розвинених країнах світу, має явно виражену тенденцію до наростаючого посилення, метою чого є надання цьому виду транспорту у найближчі 15-20 років домінуючого положення, а потім - майже повного витіснення їм автомобілів 3 двигунами внутрішнього згоряння. Інтерес до електромобілів у деяких країнах планети обумовлений найперше екологічними міркуваннями (наприклад, у Норвегії і Швеціiі) i не викликаний скільки-небудь гострою економічної необхідністю, водночас, безсумнівно, зазначені міркування у перспективі будуть грати все більш визначальну роль і носити глобальний характер. У світовій індустрії несподівано з'являються виробники електромобілів 3 числа фірм, іноді вельми великих і авторитетних, які раніше автомобілі не виробляли, як наприклад, японська корпорація «Sony», їх інтерес до 
даного напрямку, можливо, пов'язаний з його важливістю і перспективністю, водночас такі фірми можуть володіти великим інноваційним потенціалом і фінансовими можливостями, що робить їх вихід на ринок цілком впевненим. Ключовими гравцями на світовому ринку електромобілів $є$ як традиційні країни 3 більш ніж віковою історією виробництва автомобілів, такі, наприклад, як США, Німеччина, Франція, Японія, так і Китай, чий динамічний розвиток поширюється на багато сфер, останнім часом також і на інноваційні. 3 технічного погляду електромобілі загалом помітно простіше автомобілів з ДВС, у них просто відсутні багато звичних вузлів і механізмів, заразом ключовим елементом електромобіля $є$ акумулятор, що відрізняється високою вартістю, але останнім часом зазнає досить активне вдосконалення. Багато передових електромобільних країн, зокрема, європейські, мають певні проблеми з виробництвом акумуляторів, тоді як країни Південно-Східної Азії, наприклад, Китай, Південна Корея, займають тут передові позиції. Україна може бути одним з учасників світового електромобільного ринку, виступаючи в якості виробника найважливішої сировини для акумуляторів - літію, а також окремих вузлів автомобіля, різних приладів, зарядних станцій, або випускаючи готові автомобілі, що було б краще, зрозуміло, це можливо 3 набагато більшою ймовірністю тільки у співпраці 3 провідними автомобільними концернами світу.

\section{Список використаних джерел}

1. Михасенко Е., Кен Ф. Только электромобили к 2025 году: Норвегия все ближе к воплощению плана. Deutsche Welle. 25.01.2019. URL: https://p.dw.com/p/3Byfs.

2. Volkswagen plant 22 Millionen E-Autos in zehn Jahren. Volkswagen. 12.03.2019. URL: https://www.volkswagenag.com/ de/news/2019/03/VW Group JPK_19.html.

3. Жолквер Н. Борьба с изменением климата: какие меры приняли в Германии. Deutsche Welle. 20.09.2019. URL: https://p.dw.com/p/3PjEr.

4. Heuzeroth T. Plotzlich fahrt bei der Sony-Präsentation ein E-Auto auf die Buhne. Welt. 07.01.2020. URL: https://www.welt.de/wirtschaft/article204820010/CESPloetzlich-praesentiert-Sony-ein-eigenes-Elektroauto.html
5. Гурков А. Станет ли Volkswagen ID.3 народным электромобилем? Deutsche Welle. 04.11.2019. URL: https://p.dw.com/p/3SRf2

6. So teuer wird Teslas Gigafabrik in Brandenburg. Bild. 16.11.2019. URL: https://www.bild.de/bild-plus/geld/wirtschaft/ wirtschaft/300-hektar-elektrofahrzeuge-so-teuer-wird-teslasfabrik-in-brandenburg-

66081408, view $=$ conversionToLogin.bild.html

7. Первый европейский завод Tesla построят в пригороде Берлина. Delo.ua. 20.01.2020. URL: https://delo.ua/ business/pervyj-evropejskij-zavod-tesla-postrojat-v-prigo363580/

8. Ромаменко C. EC одобрил многомиллиардные субсидии для производства батарей. Deutsche Welle. URL: https://p.dw.com/p/3USSg

\section{$\underline{\text { References }}$}

1. Mihasenko E., Kyon F. Only electric cars by 2025: Norway is getting closer to implementing the plan. Deutsche Welle. 25.01.2019. URL: https://p.dw.com/p/3Byfs. (in Russian)

2. Volkswagen plant 22 Millionen E-Autos in zehn Jahren. Volkswagen. 12.03.2019. URL: https://www.volkswagenag.com/ de/news/2019/03/VW_Group_JPK_19.html.

3. ZHolkver N. Climate change: what measures have been taken in Germany. Deutsche Welle. 20.09.2019. URL: https://p.dw.com/p/3PjEr. (in Russian)

4. Heuzeroth T. Plotzlich fahrt bei der Sony-Präsentation ein E-Auto auf die Buhne. Welt. 07.01.2020. URL: https://www.welt.de/wirtschaft/article204820010/CES-

Ploetzlich-praesentiert-Sony-ein-eigenes-Elektroauto.html

5. Gurkov A. Will Volkswagen ID.3 become a national electric car? Deutsche Welle. 04.11.2019. URL: https://p.dw.com/p/3SRf2. (in Russian)

6. So teuer wird Teslas Gigafabrik in Brandenburg. Bild. 16.11.2019. URL: https://www.bild.de/bild-plus/geld/wirtschaft/ wirtschaft/300-hektar-elektrofahrzeuge-so-teuer-wird-teslasfabrik-in-brandenburg66081408, view $=$ conversionToLogin.bild.html

7. The first European Tesla plant will be built in a suburb of Berlin. Delo.ua. 20.01.2020. URL: https://delo.ua/business/ pervyj-evropejskij-zavod-tesla-postrojat-v-prigo-363580/ (in Russian)

8. Romashenko $S$. The EU has approved multi-billion subsidies for battery production. Deutsche Welle. URL: https://p.dw.com/p/3USSg (in Russian) 